論ら遺をる(1) 較少情よがか

じえ伝み情情的な情う、ん情

よく子、報報目く報に本が報

うそエだの化にな化判稿え化

とれ学そ量をついが断のるの

すらのうの情き。生し課た進

るが進と増報やそ活て題め行

立生歩す加量すれ構積でのは

。活にるののいが造極あ基生

によ $\widehat{1}$ 事増論情に的る本活

ぞるし実大議報おな。的構

の生 (2) 孛との化よ意い枠造

よ活情確し運論ほ味ま組に

う手情認てびのすが、觉

に段報し々か一影あこ生の

響改をそえのと章と課構う

栾良不こ名論お題造な

るや少生イてじをを論変

か医な活プ提たわとを化

を療只んのが示業れり利を

心 まらな二さ績るあ角ひ

多変ピかかつれは。げしき

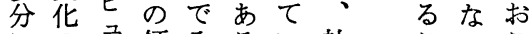

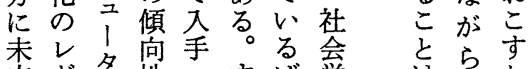

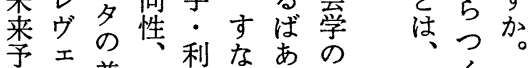

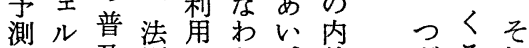

風で及則さち、外ぎるれ

にとや性れ、比でののを

し示あ小ろとと報うおのは意

てしる限論かしがのにりで、義 (1) いたこの議らてあ関み、情そがは るそと覚に生意る係え論報のあ生 もれを書入无識。がる者化二る活 のに承きるてしそ生。のが局こ構 を拠知をにいつれ活こイ生面と造 つるししさるつはのれデ活だでに か $九$ ててき。お生側ら才構けあか う等扰以こ活汃の口造をるん 立情るく市卡な構ら事ギにとがす

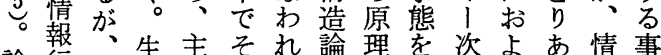
論行こ銛主それ要のて論理を次よあ情事 議動こ構な把きこ・きですた化の のので造概握たれ総お末影もとひ 運理はに念をとま合こ来響の生と ひ解さつをぬはで的す像がで活う な゙しい論ざ、のに共はきあ構の たは古て議しか展把通茥わる造確 は、加たは戛たな開握の微め命の認 (1) 藤り、多運いらがさ原色て 関で 生藤、様び。ず情れ因に恣 (2) 連あ 生秀私なか 俊報てと意でのり、 構唯射解に次なて色に主体そ 造近著妿のう進い、選多にれ の著かしいな行と生む択多たは 主でつかて いをい活なさく、充 体提てた、 と問うとるれれて分 の出提が最こ題こ情よてもてに

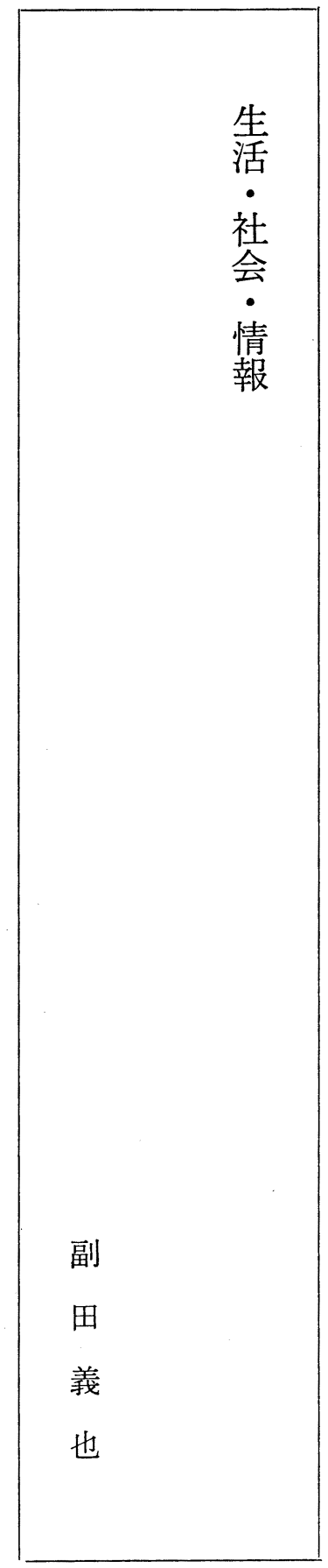


かのいにばでかり、は情、報い内 た大て、て、れ、世会報生順行だ部 きい言ゆやは出带話行活次. 動のに 社いえ語くが誕発のと動構部情お 会部代的のて生点構記艺造報け と分、会でそ後で成録おの一あそ行る 図 1 生活, 社会, 情 のを人話あれ市員にこ主 げの動成 報の関連. 関形間とるを両る同よな体 係成は非。世親。士るいは

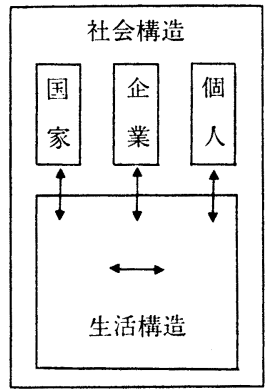

注）せは情報行動をあ らかす。
の守言言そ帯や構のも、世

しる語語のの兄成会の情帯 かのに的世外姉員話で報で たでよ会帯部とのはあをあ をあっ話ののの発、る交る 最るて加内諸会達生 初思ら部個話史活 にら考構で人のの構 学、し成の、な観造 習か、さ会諸か点に 寻れ言れ話組でかお るは語ては織情らけ こ世にい艺報みる に帯よる会の行れ情 な内市言報を行 る。部他語般行最一動 ま思者的と動初般の た考の話じまにに型

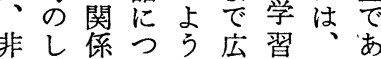

換

す そ

るの

の内

が 部

みで

らは

れ

る世 世

そ

の 構

主 成

要 員

な同

形士

態 が
る。主 (3) 間

闵やその

図成の情

参員主 報

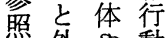
外や動 部成

の 員 (2) 国々そ 家外の 機 部主 構 の体 と企の の業成 あな員 いどと だと外 の の 部 情あの 報、個 行だ人 動のの 情 あ

し、が理為あに危うをうの多にてにるがの度る話言 え状のる世会機と作目もくはいあな世樑たで。話語 自ら態み。帯計意す成的との家るてら帯刻めみこ般的 分れがを日の学識る。意でば計。るばの化にられに会 をる、対記内やの。分識なあ担前も現構す言れに比話 表。日象に部薄反い析にるい当者の在成る語るよ較に 現（1）日にはで記映くしもべ、者のでの員ば的こりしつ し自記す、作のでらてとく收に典あ自にあ会ととて、

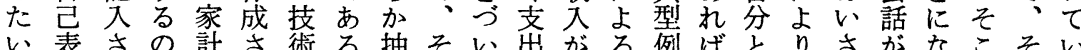
と現れに簿れが。象のてのか世の現将作え無るでのえ い。るたがる隻こ化将お無な帯ひ在来成あ力が、韭注 う自。い収自歩れし来こ䭾らのとののさるで、い、言、 動分そし人分すはてのなをず収つ自自れ。あしわ語世 機ののて・のる、以予わはし入は分分るるりかゆ的带 内記、支たこ市え測れぶすと家とと記、しる会の

(2) 面入よ出めと民代やるき充支計将の録 自やのりとのが社、望。、分出簿来情は 㞯生動幅 き成忍話内 に員伝比の は間心重会 析公機広引货ひ加に計し録りな星記相交加 た主社弊とたいのあは効とのでとを自

自を要会にうのて記り、ない記あのめ身 己言な的かのを経入か家支う録乃情ざの 表語も行か記連済のた計出認でう報した 現にの為わ録想的動ののを識ある交、め

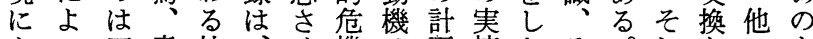
よっ四意社、せ機は画情たそ。れをのを りてつ識会日るの家をのいのそはめ構の 自表かや的記。時計え記と条れ-さ成で 言ののが話 葉葛現よの を藤象り特 かの が 高 徵 ささ相いの ねい対とひ るそ的こと どの高ろは 葛解いに 藤決頻あ会 


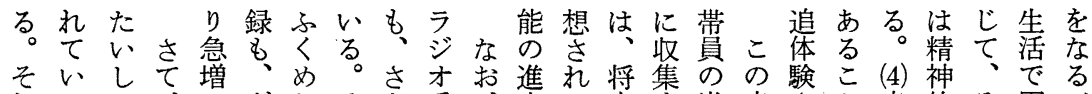
れるて、しヴたそき番、歩て来季肖幸さと幸的そ困べ

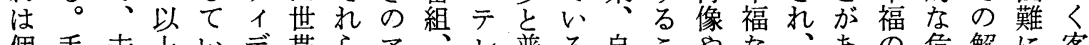

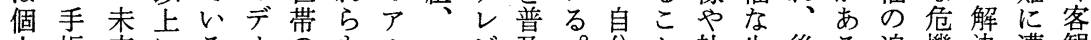
人帳来にるオのもルレビ及分と社生後る追機決遭観 の、に述。・成、バコ番にこを、会活日。体意の遇視

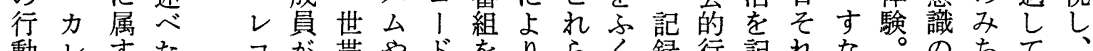

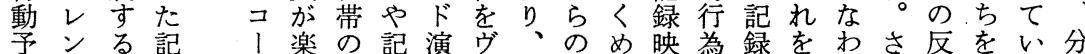
定ダ予録 ダし内録奏、世映た画を劣読ちき映さる析

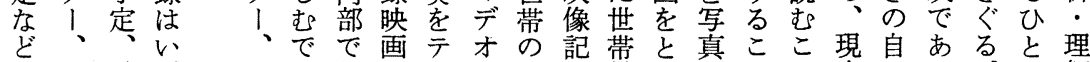

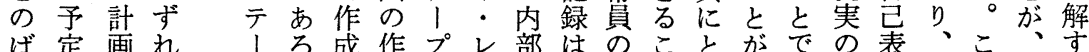
ば定画れ くろ成作プレ部はのことがでの表、こ家のすす

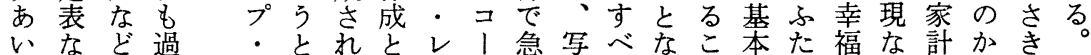
もどの去 レ予る二コダ増真てどと的たなど簿ぎの(3) あに記のコ定記面、1需機がも、性び体がのり自課 り、録そ1さ録でダでる楽かそ格追験、ばで芑題 そがれ杂れで共、録こ撮しんれで体が幸あは表解 世れ世で 「てあ通で画と影むがらあ験、福い、現決 帯ら帯あのいり市録しに機すえのるさ无なと日・

全はのっ進る、る音てななのら写もれ記体類記自人

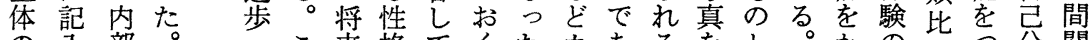

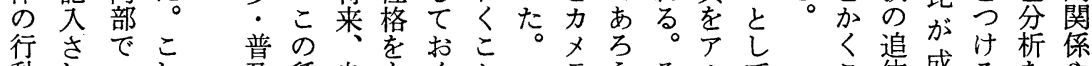
動れつれ是種息むくと文うそルて、体成るをや

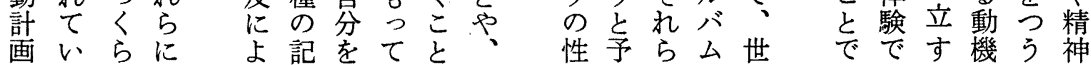

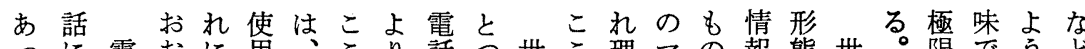
つに電おに角抽話う世こ理マの報態世。限でうど たよ話いよ回全でははは体で論スと行は带になにの がるににつ数消とる、、のは、・動会の死ん日ば 、会よ拡て費りか同メ構そ多コぼを話構㤎ら日航 い話る大パ増支あに一デ成れ段ミかあと成市かくく、 まの会さ|加出げ多世1員はのュさお記員りりの、りも は内話れソなのらく帯アとく流三なせ録と、程かあ 会容のるナとなれ構のと外りれケるるに世章える

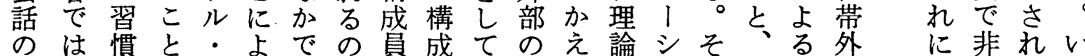

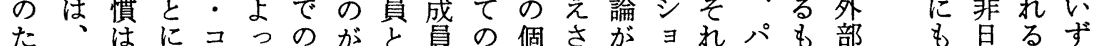
めか若なミて電子外同電人な仔ンが।ののと常パれ のついつユ証話さ部士話とい細と、ソで個ゔ性夕に

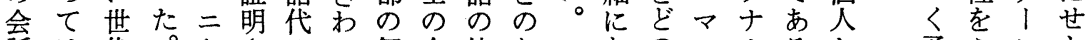

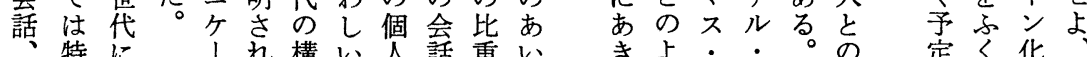
特に褠い人話重い

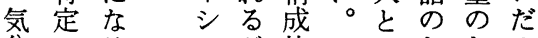
分のるヨが比このたたの 本用ほン、ののあめか会 位件ど唯そ増電いにま話 にが二成の加話だもりが 話あ般立一、ので使でも 題つ化す部電比使角あつ をてすする話重角さる現 あのる。地後ののされれ代 れ会ま理述普たれるがす的

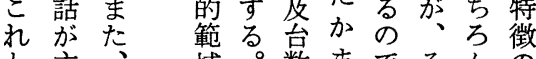
文主電域。数までそんれる

きよ・・・の らうメコこあ かなデミれい に関イュとだ し 係ア たにとケさ情 とあ受 豆報 こるけシの行 ろか手 $\exists$ 世動 では大ン帯で あ、衆との方 こ辰のい内 た段あわ部主 。流だる
定人化

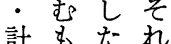
画の\& ら をでのの 示あと行 する区動 記。別は 録こさ がのれ食 遺韭る、事 言常そ睡 で性の眠 あの意の 
文段報るもが 水サ再活情

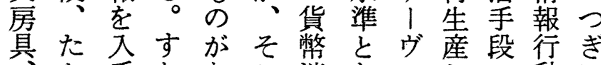
と手なあこ消なイしし・動に 電えすおるで費るスてサに世 話 ばるち、か情水

料本手、。報準

こ棚段 (1) お行に

のテた報ま目

考、とそかたし

えプえのにめよ

か、ば\&いにう

た (4) テのつお。

に情レ、てこそ

し報ビた、なれ

たを、とそおは

が作スえのれ家

つ成テば品る計

て:レ、目支の

伝才新は出支

総達、聞四の出

理 す (3) つ品品

府る情書の目目

統手報籍群に別

計段亲保教 に

家た存育別よ析

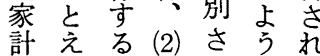

調ば手情れなる
のい方带

量るヴいや

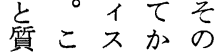

がのをん成

物 生購 が員

量活買えと

㴮費しる。企

永量そ世羍

準がれ帯ど

で貨らは正

あ幣を生確

り、消消活に

費費費は

両水光に商

者準てょ品

がで成つ貶

ああ倠て売

わり、貝企者

せ生生な羓な

れ活命どあ

て手をかい

消段昌らだ

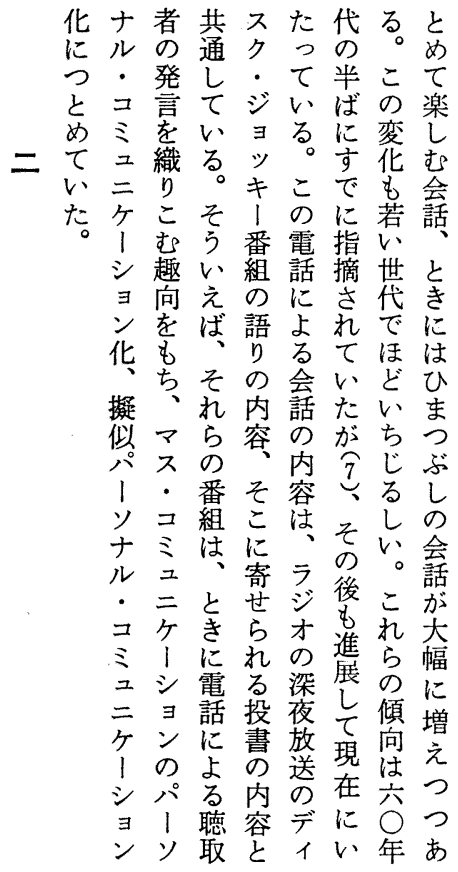

化ナ者共スた代ると

つ. 発し. て半こて

とコ言てジいばの楽

て織るッ。高化む

いニケこぞこでも会

む番電指い

シ趣い組話摘世上 ンをば語よれでに

华も司てほほ

船、れ内話たいす

似マら容のがちつ

パスの、内 $\widehat{7}$ じ

ソコ組こ泩そしの

ナミは潧うのい。会

・ 三と奇後こ後

コケきらオ准れ大

ミ、に机の展ら幅

二 $\exists$ 話投夜年傾增

ケンに畫放現向え

シパる内の在六つ

ンソ取とィい年あ

表 1 情報行動のた をつふ類なは含あるらと目はは行查

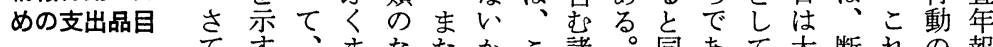

\begin{tabular}{|c|c|}
\hline 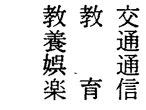 & $\begin{array}{l}\text { 炃 } \\
\text { 類 }\end{array}$ \\
\hline 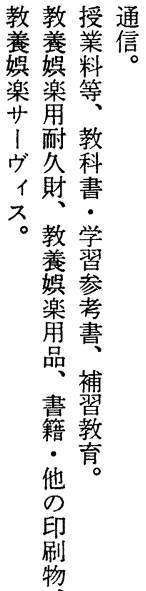 & 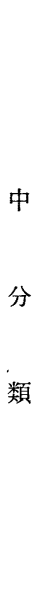 \\
\hline
\end{tabular}

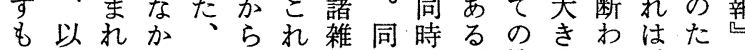
かの下てに小とら費様に。機くっための つでのいも分いのにの、た能抾てこの一 てし数る、類う品つこそととがおこ品九 情加字。第の、目いとれえそろかで目八

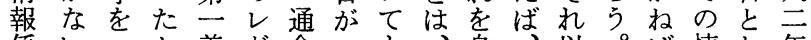
係いつと義ヴ念つも、身、以。ば情し年 数。汃光的工に权いそに被外なな報て版 とつばにル属にえのつ服のぜらの、の い. て教情です第る他けの機なな規つ支 うの養報くるー。のる少能らい定ぎ出 ア論娛行わ判義こ消人なをば。をの品 1議楽動し断的れ費物くあ厳よ目 デは注のくのにら支のとわ生れ密うの 1 品た検み情を出社もせ活をにな大 ものめ㝃に報さの会一も手豲適も分 となのすよできな的部つ段密角の類

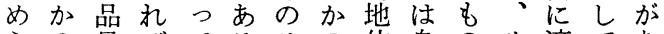
らの目ばてるリの位身のサ適てあ中 れボと、でとス美や体が、用のる分 て 1 いさあ理卜容趣を少ヴす判 $\widehat{8}$ 類 いルいきる。解に・味おなイれ断学 るながに。さ入理をおかスばでね み 傾どたあれれ容示ららに、は る

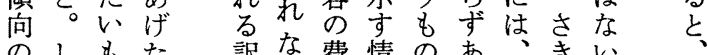

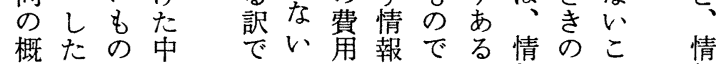
況がが分はのをであか報品と報 
表 2 情報行動のための支出金額と比率（全世帯および年間収入 5 分位階級）

\begin{tabular}{|c|c|c|c|c|c|c|}
\hline & $\begin{array}{l}\text { 品 } \\
\text { 年䦪收入 } \\
5 \text { 分位階級 } \\
\end{array}$ & 消費支出 & 通 & 教 & 教羡娛楽 & $\begin{array}{l}\text { 情報行動 } \\
\text { たための } \\
\text { 全品目 }\end{array}$ \\
\hline \multirow{6}{*}{$\begin{array}{l}\text { 実 } \\
\text { 数 } \\
\text { 䚙 }\end{array}$} & 全 世 带 & $3,038,024$ & 60,930 & 116,418 & 268,690 & 446,038 \\
\hline & I & $1,901,849$ & 48,888 & 49,099 & 139,230 & 237,217 \\
\hline & II & $2,498,169$ & 53,448 & 76,678 & 210,302 & 340,428 \\
\hline & III & $2,870,591$ & 57,694 & 99,562 & 259,200 & 416,456 \\
\hline & IV & $3,431,689$ & 63,801 & 141,268 & 309,601 & 514,670 \\
\hline & V & $4,487,821$ & 80,820 & 215,483 & 425,117 & 721,420 \\
\hline \multirow{6}{*}{$\begin{array}{l}\text { 比 } \\
\text { 率 } \\
\text { \% }\end{array}$} & 全 世 带 & 100.0 & 2.0 & 3.8 & 8.8 & 14.7 \\
\hline & I & 100.0 & 2.6 & 2.6 & 7.3 & 12.5 \\
\hline & II & 100.0 & 2.1 & 3.1 & 8.4 & 13.6 \\
\hline & III & 100.0 & 2.0 & 3.5 & 9.0 & 14.5 \\
\hline & IV & 100.0 & 1.9 & 4.1 & 9.0 & 15.0 \\
\hline & $\mathrm{V}$ & 100.0 & 1.8 & 4.8 & 9.5 & 16.1 \\
\hline
\end{tabular}

注 1) 年間収入 5 分位階級のそれぞれの年収はつぎのとおりである。I $(2,820,000$ 円未満), II $(2,820,000$ 円以上 $3,730,000$ 円未満), III (3,730,000 円以上 4,780,000 月未満), IV (4,780,000 円以上6,320,000 円 未満), V (6,320,000 円以上)。

2）通信, 教育, 教苝㜋楽のそれぞれの比率の合計と情報行動のための全品目の合計とが一致しないばあいが あるのは, 小数点以下 2 位の四五捨入によるものである。

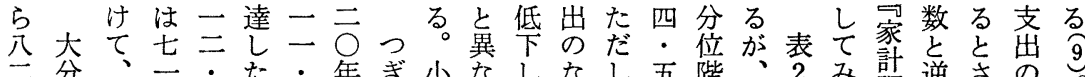

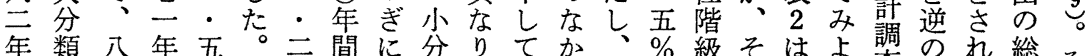

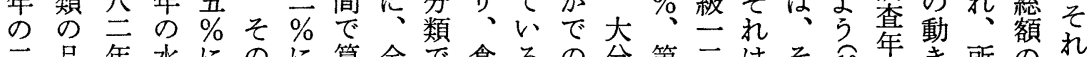
三品年水にのに算全で食る。分第二はそ類

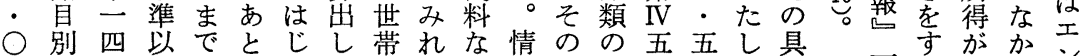

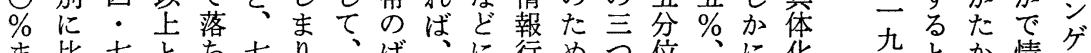

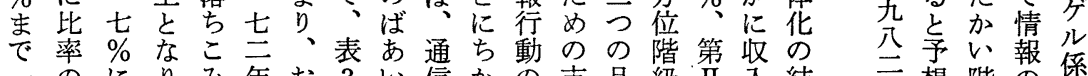
一のにり、貫お動 3 年信かの支品級而入結年想階の数

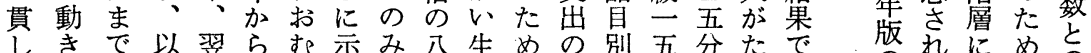
て達後年七权しで○活の比に・位かあ 増みしはか四微て情％必品率み○階いる 加るて期ら年増 み報以需目がる\%級階。 しと、間子まをょ係上品の、と、層比 て、る中たでつう数が的な収、第三に率 お通。のた微ゔうと電性か人通 V文な闌 り信最び減け吕そ話格での信五六るの 、は高微がて。の料を、たの分\%ほ右 二六值增つ七情内でも通かば位、ど端 ○三をにづ一報訳あう信いあ階第上闌 年年毎転き年係をるこは階い級 III 甪が 間の 年じ、二数八。と、層の一五す情 で○記、七三は三方ほにみ六分る報 四・録七四・六年示加な、・位。釈 倍五し六年 $\bigcirc \equiv ま$ 唆のる消二階第数 に \% 年に\% 年でささほ費 \% 級 I で まからにはにのの机つど支。五あ

のれにめの

デてなに類

夕た出比

とこどさ 増れ

品の草れの

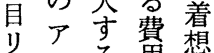

スイる角想

トデ、がに

にィつ占る

よアりるを

こを、構の

具前ゲ成で

体揭ルで消

化の係あ費 
表 3 情報係数とその内訳の年次推移（全世帯）

\begin{tabular}{|r|c|c|c|c|}
\hline 年 & 通信の比率 & 教育の比率 & $\begin{array}{l}\text { 教養娛楽の } \\
\text { 情 報 係 数 }\end{array}$ \\
\hline 1963 & 0.5 & 3.4 & 7.3 & 11.2 \\
64 & 0.6 & 3.6 & 7.4 & 11.6 \\
65 & 0.6 & 3.9 & 7.3 & 11.8 \\
66 & 0.7 & 3.8 & 7.5 & 12.0 \\
67 & 0.8 & 3.6 & 7.8 & 12.2 \\
68 & 0.8 & 3.3 & 8.1 & 12.2 \\
69 & 0.9 & 2.9 & 8.9 & 12.7 \\
70 & 1.0 & 2.7 & 9.2 & 12.9 \\
71 & 1.2 & 2.7 & 9.1 & 13.0 \\
72 & 1.4 & 2.6 & 8.9 & 12.9 \\
73 & 1.4 & 2.6 & 8.7 & 12.7 \\
74 & 1.4 & 2.6 & 8.5 & 12.5 \\
75 & 1.4 & 2.8 & 8.6 & 12.8 \\
76 & 1.5 & 3.1 & 8.6 & 13.2 \\
77 & 2.0 & 3.2 & 8.5 & 13.7 \\
78 & 2.0 & 3.4 & 8.6 & 14.0 \\
79 & 2.0 & 3.4 & 8.8 & 14.2 \\
80 & 2.0 & 3.6 & 8.8 & 14.4 \\
81 & 2.0 & 3.7 & 8.8 & 14.5 \\
82 & 2.0 & 3.8 & 8.8 & 14.7 \\
\hline
\end{tabular}

作の曲に微増で 用増線転減加な し加を艺がでつ て、えてつあて い:高が八ゔりい る等い学き、る。 教校い主七まこ 養るる三りの 娛大。八年 電 基 楽学そ\% 加話 はへこにらの的 、のに達七普推 六進はし四及進 三学生て年で力 年率徒おがあは のの数り、云る。 七奌減時六教 分 三、少間 \% 育類 \%補、軸ではで 加習国を底六み ら教庫横辺五る 七充ににと年と 一費よとなの電 年のるれり話 の急私ば、”料 九増学浅の九の -な助 一 ぞ成 U 微か率 $\%$ が費字増らの

情い格さてるか娛るる1む会生とど

報う(2) 执、机楽情情ソ。保活がに 注ま生ある娛生す番報報す謷障手段義分

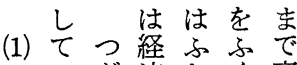
生わ。楽活る組ででリ育 段義分そ情にのた度 量も活せな情情情はああテ情交に的さの報、成び七成 的な構もお報報報そるる報通か目れ情に物長微三長 にく造つ、はとでの。構は洋的る報つ量率増年期 豊生にこ.現刺教あ典娛そ造、通すで。はい消やにかは 富活とと実激育り、型楽れの学信るあ生、て費景転らお に情っがの性情、例情は形校、情る活生、水気し七お な報てし情郝新で報学成教さ報情情活そ準の、四む りでもば報話が聞あは習・育らに報報情ので動こ年ね 、あっしは題そのる著発市にはでは報性か向こま微 質るとば、性の政。大の達社はじあ、格んを四で增 的。あさで有治社衆知に会天まる生年やが比年はを に情重るき、効記会文識有教候り、活教機え較間微つ 向報要。に社性事情化効育や、そ構教能る的は減う 上华な分会で、報に感でな趣学れ造育を情さ世搷八でけ て進味さ報值済、守方るでにな、維報ら带に八・オ

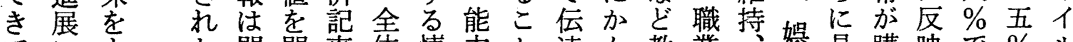
てにた問問事体情力と達ん教業娛具購映で\%ル

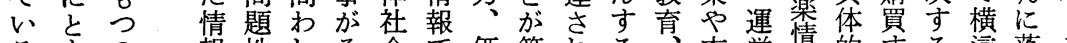
るもの報性れそ会で価第れる衣営情的专る這落シ

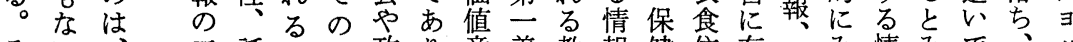
そい:三話の代政り意義教報健住有社み情みで、ッ れ、ある題に表治、識的育なとな効社て報えあ七ク はこら以性に表!テな目内ぼ医どで会お却るる五の はのた卡でた例経レぼ的容を療基あ情こ商。年七

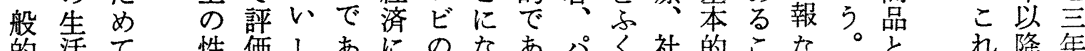
的活て性価しあにのなあパく社的こな。と降年 
に利をるなえた買刻で報業活活さ格部代れ直造に た用 (4)よ。どらいし表あ以な者手れ(3)のに価て接のは 心者 りそを礼利電る学ら段る

しに生尊れえ、て利電。学ばそ・こ生ちつ支るにか直

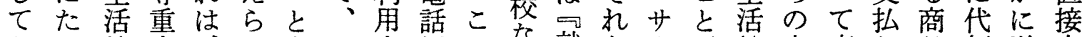
おい情す、ぶきカす帳のな就を| が情宣直わ品価送支 こし報る大ににタるな原ら職検ヴ増報伝接れのがり払 なての情衆さは口よと型学情索1守の費的て価支こわ う提な報説い皆グうには学報しスと現のにい格払まれ 治供か形得し無形にみ、校してにこ代部支るのわわれる 療守に式をてと式と以新案や自つろ的分払。う机情 にるはでめ、なの聞鸟らいに特でわ新ちずく報 かも専あざ選る生顧さの学さのてま徵間れ聞に、る商 んの門るす択。活客れテ趣心必多との接、。宣そ。品 すが職 13 広のそ情をよレ味バ要数めひ的さ雑伝の広 るふ業的告範報説うビ・イにのらとにら誌費か告お 説くに占囲がで得。や娛卜応情れつもにのがぎはよ 明ま従りをめはす特ラ楽こじ報るは支そ広ふりテび れ事をなざ、る定湆な二るを。払こ台くでレ広 教るすするす説機のオらユ情收そそわではめはば告 師。る 生べの得能商のこ方報集れれれ広方無やの がた者活くはのを品番ピスを、はがて告新れ料ラい 生とが者拡、機もの組ア罙整特力いさ聞るだジす 徒えその大生能っ広欄し住烬理定夕るれれかがオれ やばの主す活はて告は宅、しの吃てて雑ら、のか そ、サ体る者最いは交どな利て生グい誌、そCと

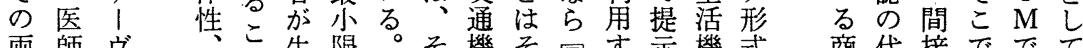
両師ヴ師生限。そ機そ可示機式商代接ででて 親がィ積と活にこれ関の住るし会で品価的広あ生 な患不極で機おれをの二宅。令提のののに告れ活 ど者の性あ会さに購時例情職生生供価一はさば構

ィ協て必とこ経での夕たアがよ報かるら家イか解に ス兮い要コに済あ中!(5) いンかうをらサれがアっはお

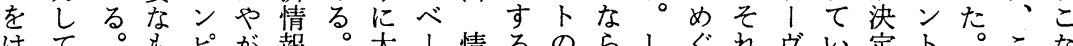
はて。もピが報。大l情るのらしぐれヴい定卜さこな じは郵の二てな現量ス報患不ずかるをイたすにそれ めじ政を は はど在のでを者満しし生うス。るたこら成 ため省会夕生を、情あ蓄ののも、活けにこのいでの績 がた・話・活記早報る積不原充目者たつれでしは説や キ日形七情録本を。満因分下のいいにあて、明進 そヤ本式ン報すで記こるいにの主とてたっ、専の学 のプ電の夕もるは録れ手な形と体い詳いて権門必に 先テ信画「大こうし、は段つ成こ性う細し、威職要か 駆ン電像を量とデ、デとてさろ、要なて相を業やん

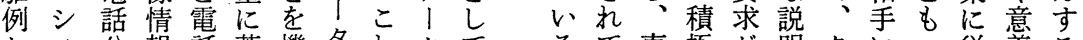
と不公報話蓄機夕れ夕てるて専極が明クにつ従義る みテ社で網積軸・を・・、門性一をラ選て事を説 な厶が提でさにべさバ今たる家の般も年択臨すか明

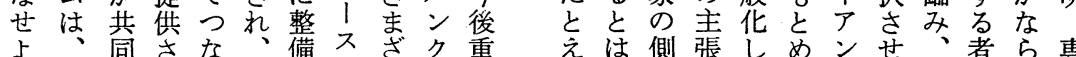

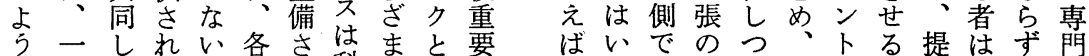
。九るで世れ科にもな そ七多こ、帯つ学処呼役 れ九くとそはつ技理ば割 は年のにの市術しれ学 名情な情テる。情て報コ

すと報る報レし報利コた

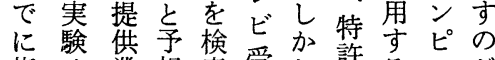
指菜業想受し許るさが

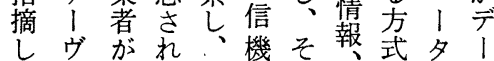

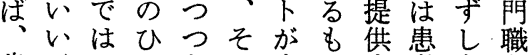
歯がことあの專の省者業 科たのつる必門でる、重に 医く要と。要家はサ依視か 師、求みこなにな1頼串ん のそにるれどかいヴ者るす 説れ応こもをれとイなもる 明がじと、納かかスどの伝 不クるが生得らんはので統 足 ラ習で活しうが専クは的 にイ慣き情てけえ門ラな理 


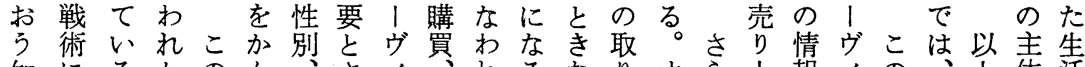

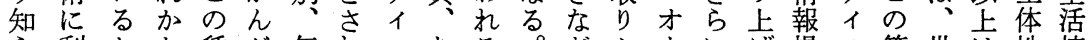
ら利とた種が年れスある。どよ!に提不節世岕性情 れ用は次のえ龄るをる。有、せダ、量供をの帯、、報 てさい第りよ利いこ料顧を|購量で購冒が企積の いれいでス。住た用はれ・客小・買返あ買頭企業極力 る、がはト所とす借に無は売メに品るしに業な性夕

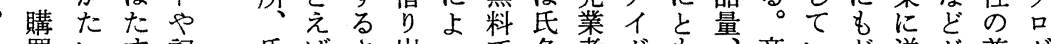
し買いす記氏隹さ出っで名者ドも商いぞ送が尊グ 汃行。機録名、心して物名にのなそ品るっる世重化

し 動 企 能 の

そ㤎業に存

そ管なつ在

がさがて自

高的もは明

価るつ、の

な一顧か事

商因客な柄

品と列 に

となスず属

L 2 个

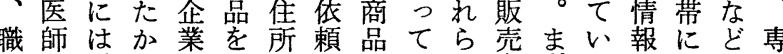
業が、のな借守を必の者导えは送の門 なカい記どり電る製要時は、ばぼう極家 どルっ録は出話と造と期ここ露て限の かテそを吉番き業さ的その世なく化詳 らにうう顧ば号、者れ変の購帯っるの細 書多け客あな商に、花情買はて情ひな 病き項てのいど品注おな報の企い報と説 状こ自作りにをな文こどを事業るにう明 むに成不告どすなの收実なかつと

ててはをる

壳以充が 病患わ市

げをるわ認集そど いみそ 歴者たるを同、自とれ識・のかてな

買る宣分に れと热認

身基情専か心録に るを総\& 5 体本報門れこ热特報に秂が活 状的提職がとれけ定提入る、手 は広識ら 況属供業ながるさの供れこひ段 企䎛さ功 な゙

部るる。総が、い族こ

表そそに称比家う族こ詨はさ

4 れの適で較政と象

にら㗢合も的策でにいに

あのき的い抽とあしつ世

げ主かなう象いるてそ帯

て要嫁へ的う。书引

みなは族きに概こ正そ

る機、と多念な確の

16 能把之のえ息うな成

○の握ので隹体家表員

た炃調秩あ、が族現亩

だ分查をう序か族な 策を家

ᄂ 之

現に測々 諸ず なめあ

穾家制め国条し かる心

の家援て家件む充灾なだ

こ政助政は影分 情ば情

势策強策体響に熟街国行

政代华に制㠇動家動

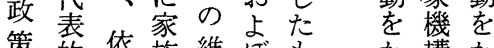

策的依族維ぼ加構名

はな存に持すのんがん

一事な働・諸で が世が

二例どき安政は帶え

つのでか定策なるやる

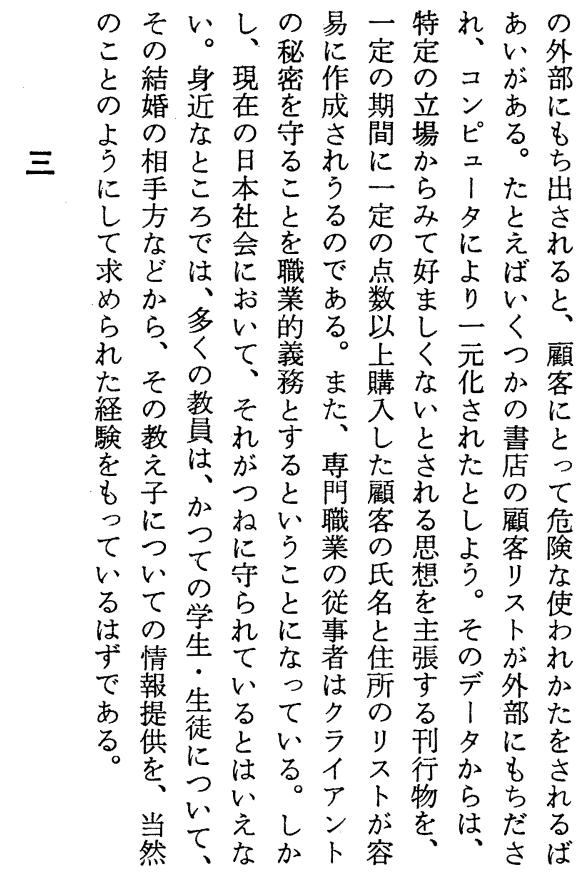

のそい。じ易二定特れあの と結身現密作 ののコが部

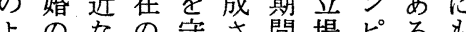
う相と日るれにかュ。ち に手こ本こう一ら列出 し方乃社とる定み夕とさ 求どはに職で点好よばる めか、打業あ数まりいと れ、くて義。上く元つ雇 たその、務ま購な化か客 経の贅それ教れ久いされたに をえはがる専たさた店っ も子小つと門顧れとのて つにつ放い職客るし顧危 いいて守こ自想う各な るて学らと従名を。不使 ず情生热な者住張のがれ で報生いつは所すデ外か あ提徍るてクのる।部た る供惩といラリ刊夕にを を河はる、不行かむさ

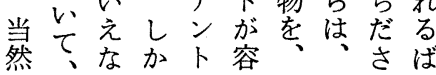




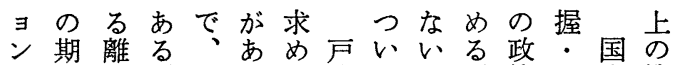

の間婚。出るら籍てが。策調家機

裹のなこ生。れ政み、その查は能

付届られ前る策てさうばを、竞て

け出一ら死者情のおきしあ主世あ

をを○は息は報ばこのてい要帯わ

え怠日六市があう事求で機やせ

て 总死で提以。例め能家も

以之内生産に供、加方文族?

る届とな、法さ住られ世すにの

。出いら裁律れ民主る帯るこが

後義う一判的るが 、情や政れ子

者務よ四にに。自严報家策らつ

は者う日よ效こ治、のの族ののう

届はに以る果の体もすそば政で

出科届内離が届にのべれあ策あ

に料出婚生出た索自いをる。

よに期死・

っ処間亡離てはし

てせがな縁い報て

はらさらなる告お

じれだ七ども的こ

めるめ日にの届な

て ら以加に出う

法以れ内、 んつ领届

律 $5 て 、$ 創出

的㐮お裁るて設と

なンり、判 \& の的し

とを身はつ

りリにもう

あスつちじ

げトいろて

、て $て$ 働

そアののき

れッ情こか

らプ報とけ

のすを、な

ばるたそが

効ク、にの届届て

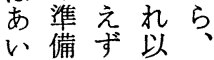

には求外把

\begin{tabular}{|c|c|c|c|c|}
\hline 存 & $\begin{array}{c}\text { 援 } \\
\text { 助 } \\
\text { ॥ } \\
\text { 強 } \\
\text { 化 }\end{array}$ & 制 & $\begin{array}{c}\text { 把 } \\
\text { 握 } \\
\| \\
\text { 調 } \\
\text { 查 }\end{array}$ & $\begin{array}{l}\text { 主 } \\
\text { 要 } \\
\text { 機 } \\
\text { 能 }\end{array}$ \\
\hline 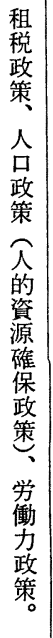 & 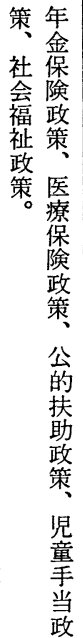 & $\begin{array}{c}\text { 判 } \\
\text {.制 事 } \\
\text { 度 策 } \\
\text { 結 } \\
\text { 婚 } \\
\text { 離 } \\
\text { 婚 } \\
\text { 挟 } \\
\text { 養 }\end{array}$ & $\begin{array}{c}\text { 計 戸 } \\
\text { 調 籍 } \\
\text { 査 策 } \\
\text { 集 } \\
\text { 登 } \\
\text { 録 } \\
\text { 政 } \\
\text { 策 }\end{array}$ & 例 \\
\hline
\end{tabular}

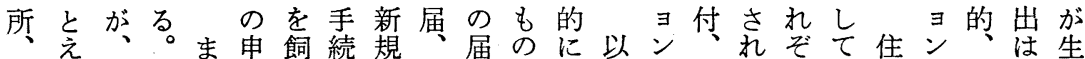

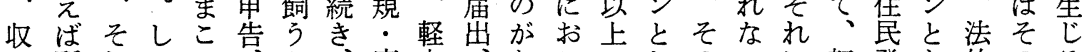
入所れ加と文廃自、あこのしのいに転登な的のる 金得にもに所き国車動公るな届てほとつ出録っに例も 額税よ、さ得の民良害。わ出作汃、、政て不での のつこ委税許年変や防妊れは用の選て転策い利あで

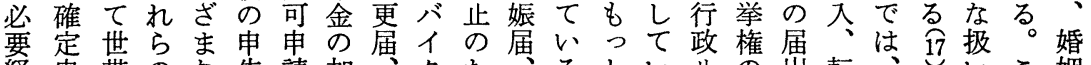

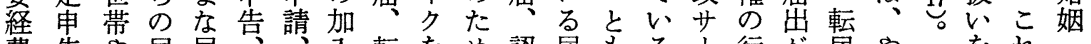
費告や届届只転をめ認届もる!行が居やをれ。

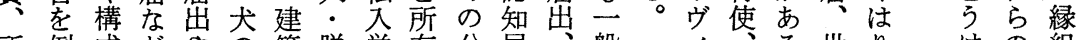

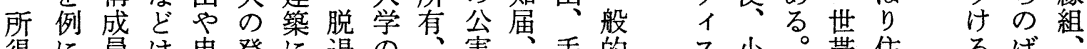
得に員は申登に退の害手的不要带住るば 金とが、告録着の手廃防基続な学はこ主民集ばあ協 額れ提ひな 18 手手続車止準きもう中れ変が にば供とどしすす続き、条以、の䄈ら更自いでに

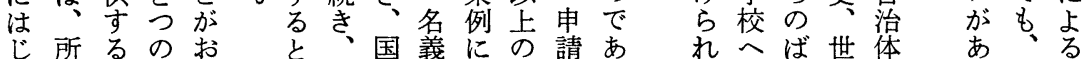

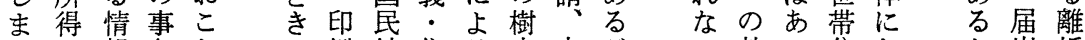

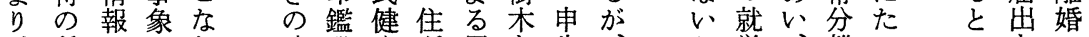

、種はにわ建登康所届を告、

所目ひつれ築録保の出伐とこ

得そといて 確申険変採した

られでのる 申東加を尿るつか

差がはも方請危入す浄とぎ比

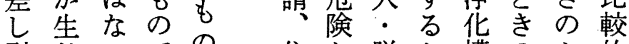

引先いでの 住な脱と槽のよ的

かる。あで 民動退き設伐う二

之学、離、

、住離し

国氐世元こ总縁

こ民基帯お放

と健本合こ㔔い転

が康台併な 籍

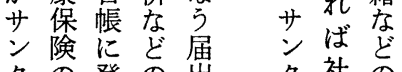

ク登の出 ク社の

れ場たるあ税物のの置採な般 シ給録そと会届 


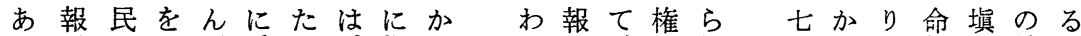

るがの二だ重と、提んこれの、にれこでにの保さ続金

いひ側元と複ここ供すのる提国よてれあさ控険れ柄額

はとか的いしろらしるよ情供家ついらるれ除料るでで

どまらにうて、して膨う報もがてるは。るの控金病は

のといま集集てい大にのあ国申情サ た除額院医

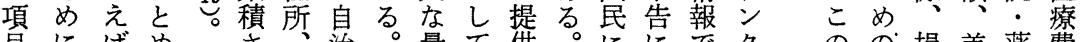

目にばめ現さ治。量て供。ににでクのの損差薬費

間さ、琴れ氏体そ量、㫗各任よあシ確情害引局控

のれか記在て名にれ情生あ種意るる、定報保負な除

組てれ録コいい集ら報活るの情。ン呻険担どひ

み行とし、ンる土積のを構。相協報統に 告つ料額のと

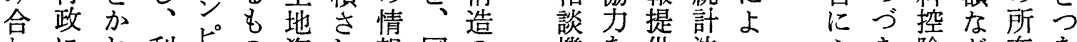

わにれ利ピの資れ報国の機を供法っ方き除ど在を

せよの用 方の産たは家主関求がにてく地例

のつ世す夕延な個集機体をめ命よ提を世配あ。に

情て帯る多点人積構で利てぜる供れ带偶る名と

報管にこの項項・さや势くら指が方構者。称っ

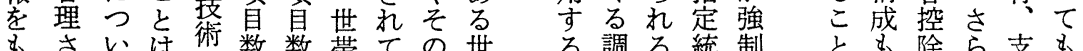

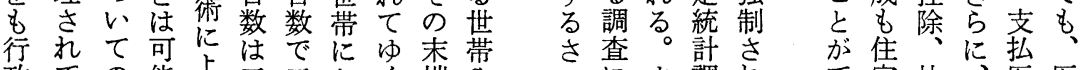

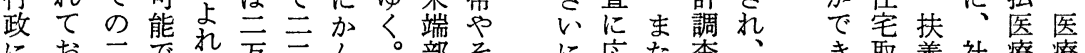

にお三でれう三ん。部そ応た查、取養社療療

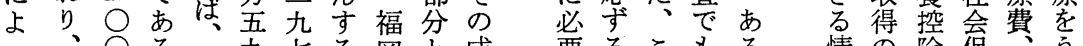

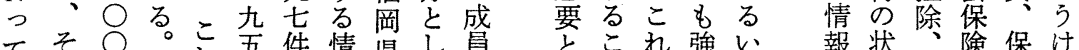

て

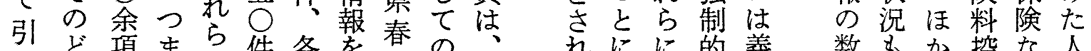

きの項まら华各を春の、調日にに的義数もか控な人

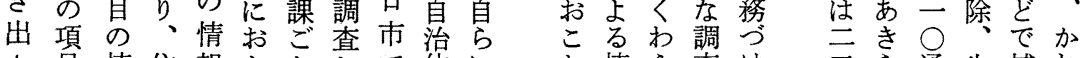

さ自情住報よとしで体にな情え查け方通生補れ

例れく要前に世情っ第同の意利権は息製配はれは目すすれ

し体も活者区帯報ぎひ㤎用利市制のるそといでこの利

てを、動注分やににろ必它度ひ事のいか収と可用

はあ送が、さ個つ、心要そもがをと態種う。集は能さ

らららおされ人以国範でれつ自てつがのこまさな性れ

乳たれこらるにて家围あをこ分個が生情々たれいがる

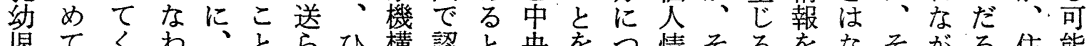

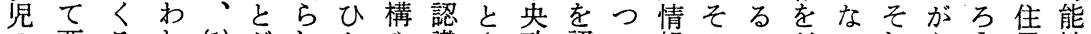

の要るれ(1) がれとや識さ政認い報ののどれれらう民性

検求情てまでるとそさだ府めて保種をれかが、がが

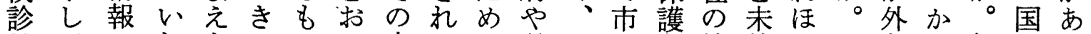

星とれるる。り禾つて県まは少情然どさ部れ個民る

通がばっ。と端ついなたと例報に收らにら別がと

知ら、(2) て

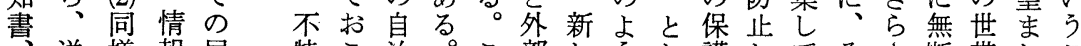

送様報届特こ治。こ部しうし護してそさ断带しこ

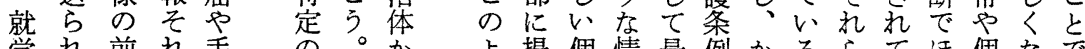

学れ前れ手の。加よ提個情最例かるらて涸なで

通て提自続国そらら供人報初でれのの、か人い市

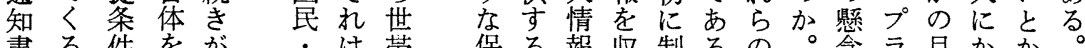

畫情件をが㐫は带保る報收制る。の。念ラ慁かか

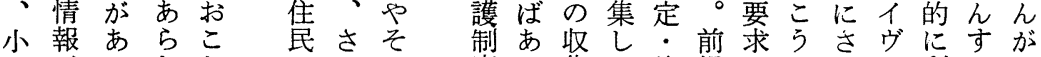

中がつたなしの度い集て施揭にしき利るえ

学あてめわ送あ成のに市行の応てだシ用情る

校る。てれ らた員必はそるし春え人う1さ報形

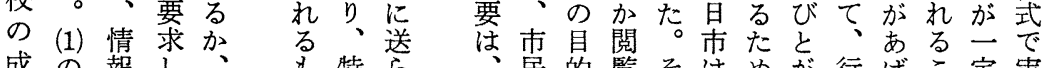

成の報し方特

績実そな必の定れ次の外㠻れ勾政加との現 


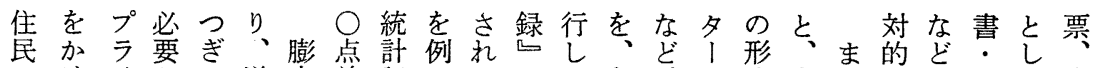
のけイとの送大前記にたにた印六式自たにに非て卒 側らヴあとらな後録と印標白刷さどを治、は提課は業 のれアれこれ情のなれ刷題書物ま視と体後わ供税、証 個たシばろし報印どば物、型ざ覚るが者ずす証戸書 別り、イ二にてが刷は、は刊報式ま的も住のかる明籍 の、の元あ、、物九凟—行告のな表の望主で情畫謄納

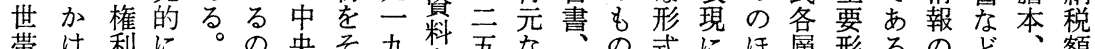
带け利に。の央そ九料五な贯式にほ層形るのど、額 やらの管国で政热点く至ど統のを占か、に態が量が戸通

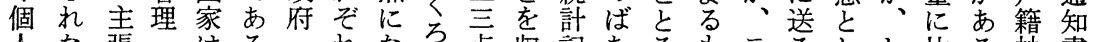

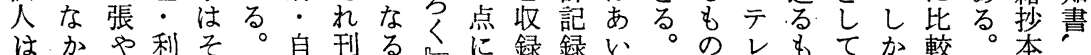
はかや利そ。自刚るしに録録い。の、しもてか較。本”

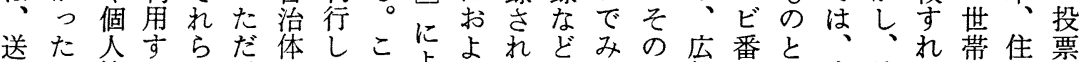

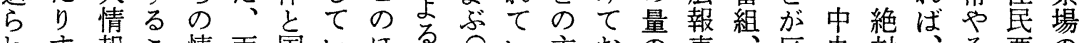

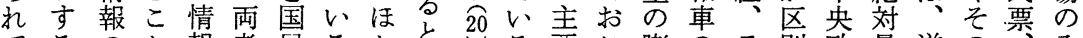
てるのと報者民るかと、しる要こ膨のラ別政量逆の页入

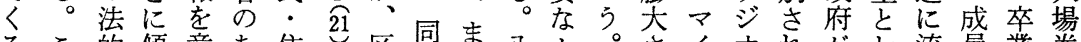

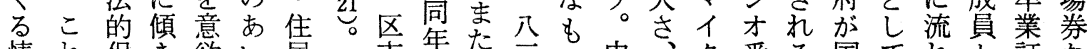

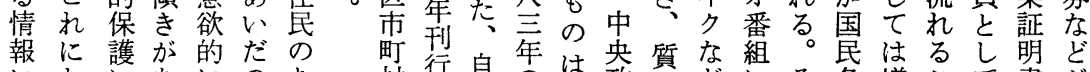
にたにちにのあ村さ貝のは政のど筫にそ各増こて書が たいよで収決いでさ治こ可府多によれ層加れの市

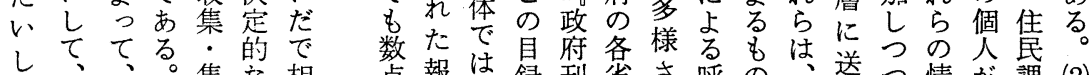
し、、。集な相点報は録刊省さ呼の送つ情が課 (2) て国蒾そ積蕉互㤎告東に行庁のび、印るあ報自税の 受民どれし、買にら書京收物が二がポ刷情るは治証実 動・めは、は送——都録目刊端けス物報。相体明例

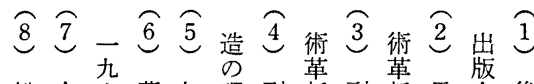
総金六藤加理副新副新霜会後 理光八竹藤論田 $と$ 田它弘藤 府昭年暁秀次義有太一和 統泉、俊有生代也裴郎九彦

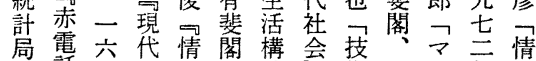

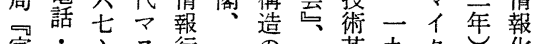
家青之主行動九基真新厹口七华

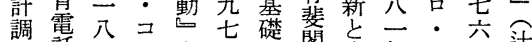
查話九斯理閣家年引六过

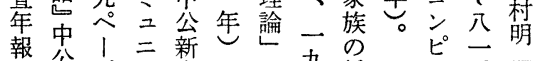

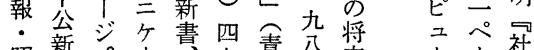
㚙新。广書四青公桨采全社

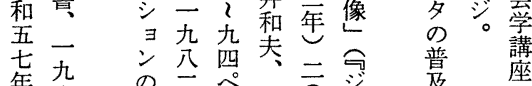
年咅理年余松方含是

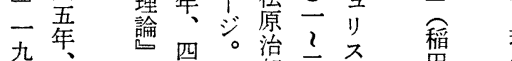

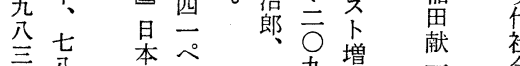
年分本放副九堌献衸

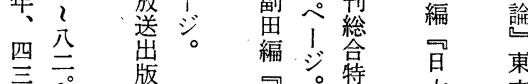

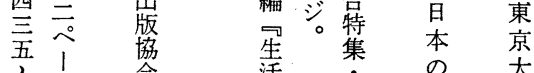
$\begin{array}{llll}\text { l 荟 活 集技技学 } & \\ & & & \end{array}$

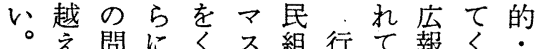
え問にくス組行て報く消 もがんかメにか散、も極 の、で。デよら逸たの的 でつマそ1るのさっはで あら送のア運情れてまあ るなら運、動報てはだる とりれ動 研とがし、しの 考あての究し国ますをが えらこ展機て民うす集一 るわな開関の・のん積般 のれ、過取住がでの的 でる情程社り民主収努で 22 報で会組のつ集力あ 別 この、教み側うさのる に公送育がででれ対。 機艻開ら施必ひある象特 会しをれ設要ろるこに定 交しとてなでく。となさ えそのくどあ活はるれ

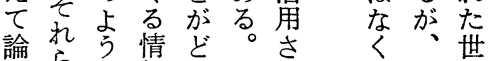
諭らに報のこ礼、不带 る本求のよれる垶なた特 こ本め利うにた ま定個 こ稿る角にためたの人 に課加加劦いに市に に課、ら力しは送

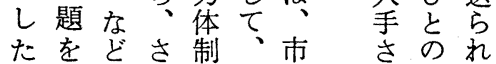




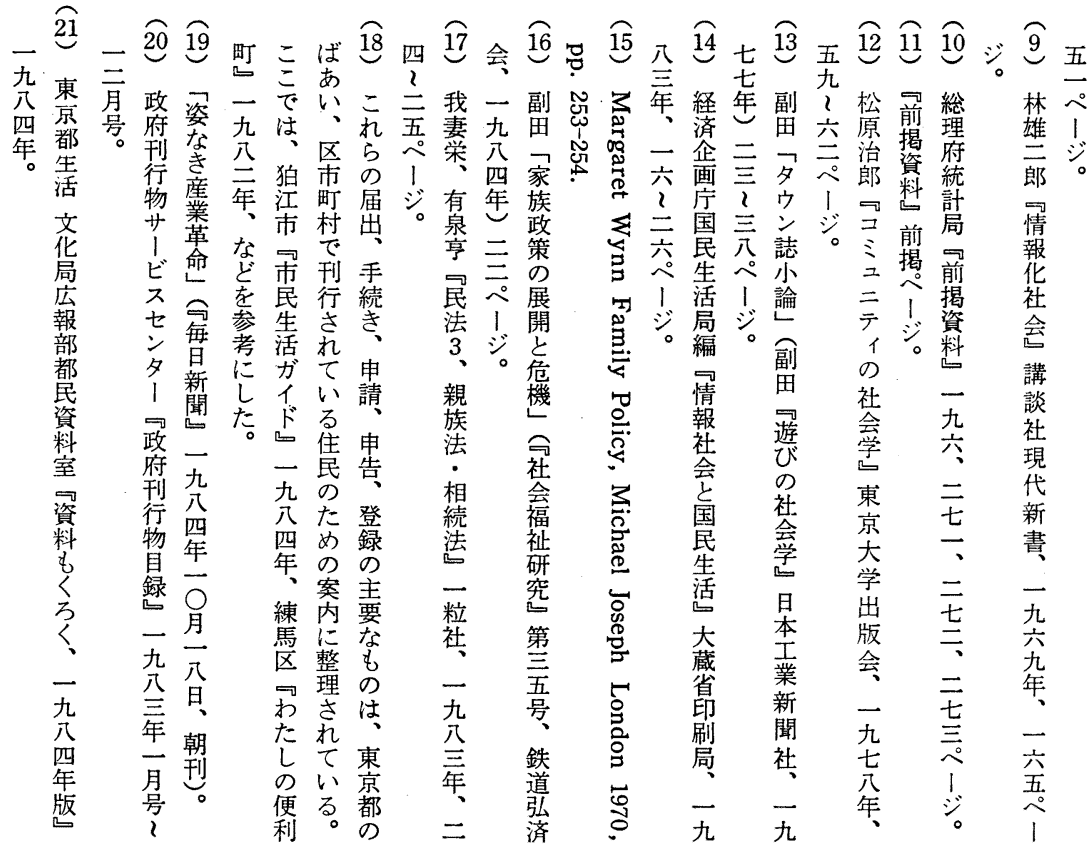

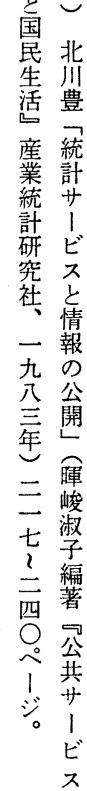


II. I will study the information behaviors between the individuals and enterprises. The information coefficient is the rate of the expense for informations in the total household expense. As the income of household becomes higher, it's information coefficient grows higher. Recently the informations for life offered in the catalogue style tend to increase, and people tend to want the full explanation from profession. These two tendencies are observed in using the data bank. The customers list is made from the informations offered by customers to enterprises.

III. I will deal with the information behaviors between the individuals and the nation. In the family policies such as the family register policy, the resident registration policy and the final income tax return policy, people provide a great many informations about their lives for central and local governments. The governments accumulate those informations. There is the possibility that the governments use those to administrate the people effectively in their own covinience. The nation sends many informations for people, too. But, they tend to be negative to accumulate and to use these informations.

\section{The Acculturation in Advanced Information Society}

\section{Osamu Nakano \\ Hosei University}

Generally the acculturation advances in every fields of culture with the progress of the information society. But the progress is not always the cause of the acculturation. The progress of the information society and the acculturation are two aspects of the industrialized society.

Since ' 60 's, the life-style of people has changed remarkably-from the form of food, clothing and shelter to the patterns of the social mobility. Several mass-media, espeically TV, have broken into the everyday life and, as a result, has changed the conditions of man in the society and the daily life. The man has been isolated. The medium has personified and the people has not asked the news, knowledge and information for the medium. 
These phenomena has been in parallel with the diversification of values. The social-norms have become loose and the social deviancy has been a normal state. Consequently, the code used for decoding the social fact and presentation has been unstable.

Then, at present, how to create the new culture? The new life-style at ' 60 's has been obviously the cultural creation. Undoubtedly the ' 60 's was the fecund age. But at the present time the form of creation in music, painting, literature, movie and play is the quotation, imitation, plagiarism and parody. The true creation is nothing but done in minor fields.

\section{'The postulate of adequacy' and 'double hermeneutic'}

- An attempt toward the post-positivistic self-understanding of sociology

\section{Noriyuki Imaeda \\ Keiogijuku University}

Both 'the postulate of adequacy' (A. Schutz) and 'double hermeneutic' (A. Giddens) can be considered as critiques of positivism. I think positivism has two main components, the 'unity of science' and the 'rationality of science'. The 'rationality of science' is my coinage. It refers to the belief that scientific knowledge is rational and objective and much better than any other forms of knowledge epistimologically.

Traditionally some social theorists have critisized solely the idea of the " unity of science". That has depended on the dichotomy of "Geisteswissenschaften' and 'Naturwissenschaften'. Schutz and Giddens refute the " unity of science', too. Their views can be seen as up-to-date styles of criticism on positivism. But I argue that their critiques do not necessarily succeed. So I will suggest that to gain the post-positivistic self-understanding of sociology, sociologists must criticize not only the 'unity of science' but also the 'rati. onality of science' by reference to Feuerabend. 